\title{
PERANCANGAN SISTEM PENILAIAN KINERJA KARYAWAN DAN PEMBERIAN REWARD MENGGUNAKAN ANALYTICAL HIERARCHY PROCESS (AHP) DAN FUZZY SYNTHETIC DECISION APPROACH (Studi Kasus : Karyawan Administrasi Universitas Diponegoro)
}

\author{
Diana Puspita Sari ${ }^{*}$, Dyah Ika Rinawati ${ }^{*}$, Ary Arvianto ${ }^{*}$, Marudut Mujur ${ }^{*)}$ \\ Program Studi Teknik Industri Fakultas Teknik Universitas Diponegoro
}

\begin{abstract}
Abstrak
Penilaian kinerja merupakan proses yang penting dalam sumber daya manusia, karena dari hasil penilaian kinerja akan terukur kompetensi, perilaku kerja dan hasil kerja karyawan dalam periode waktu tertentu sebagai dasar pertimbangan dalam pertimbangan keputusan di bidang sumber daya manusia. Universitas Diponegoro juga melakukan pengukuran kinerja untuk karyawan kontrak, dari hasil penilaian tersebut akan diberikan reward berupa kompensasi langsung yang diberi nama Tunjangan Perbaikan Kinerja (TPK), dan tahun 2014 TPK berubah nama menjadi Tunjangan Perbaikan Penghasilan (TPP). Sistem penilaian saat ini masih berfokus pada aspek kedisplinan, sehingga hasil yang didapatkan belum seluruhnya menggambarkan kondisi karyawan. Maka dari itu, disusunlah penilaian kinerja yang terdiri dari 6 kriteria utama dan 19 subkriteria yang dibangun dari model penilain kinerja "Annual Performance Appraisal-Temporary Employee (Classified or Administrative and Professional) University of Texas Dallas".

Dari hasil penelitian pembobotan yang dilakukan dengan menggunakan metode AHP (Analytichal Hierarchy Process) diperoleh bobot untuk kriteia kehadiran/ketepatan waktu (0.248), inisiatif (0.234), tanggung jawab dan ketergantungan (0.194), kualitas kerja(0.139) pengetahuan pekerjaan (0.111) dan hubungan interpersonal (0.075). Lalu dilakukan penilaian dengan pendekatan Fuzzy Synthetic untuk mendapatkan besar TPP. Dari perhitungan TPP yang terbesar ialah terbesar ialah Rp. 979,605, sedangkan TPP yang terkecil Rp.396,000. Besar-kecilnya pemberian TPP dipengaruhi oleh nilai jabatan yang dihasilkan
\end{abstract}

Kata Kunci : penilaian kinerja; AHP; fuzzy shyntetic decision approach; reward

\begin{abstract}
Performance appraisal is an important process in human resources, because of the results of the performance appraisal will be measurable competencies, workplace behavior and employee performance within a specified time period as a basis for consideration in the consideration of the decision in the field of human resources. Diponegoro University also conduct performance measurements for a contract employee, from the results of the assessment will be given a reward in the form of direct compensation, named Performance Improvement Allowance (TPK), and in 2014 changed its name TPK Repairs Allowance Income (TPP). The scoring system is still focused on the aspects of discipline, so that the results obtained are not completely describe the condition of the employee. Therefore, formulate performance assessment consisting of 6 main criteria and 19 sub-criteria are built from a model for assessing the performance of "Annual Performance Appraisal-Temporary Employee (Classified or Administrative and Professional) University of Texas Dallas".

Based on the result on the research carried out by using the weighting method AHP (Analytichal Hierarchy Process) weights obtained for kriteia attendance / punctuality (0248), initiative (0234), responsibility and dependence (0194), the quality of work (0139) knowledge work (0111) and interpersonal relationships (0075). Then an assessment with Fuzzy Synthetic pendekatan to get big TPP. TPP is the largest of the calculation is the biggest is Rp. 979.605, while the smallest Rp.396,000 TPP. The amount of the provision of the TPP is affected by the value of the resulting position.
\end{abstract}

Keywords: performance appraisal; AHP; fuzzy shyntetic decision approach; reward

\footnotetext{
${ }^{*}$ Penulis Korespondensi.

email:diana_psptsr@yahoo.com, dyah.ika@gmail.com, aryarvi@yahoo.com, marudutmujur@gmail.com
} 


\section{Pendahuluan}

Kinerja seorang pegawai bisa kita ketahui baik atau buruk, apabila adanya suatu penilaian. Kinerja karyawan juga dapat dilihat dari tingkat keterlibatan karyawan (Berdarkar dan Pandita, 2014) Penilaian kinerja merupakan evaluasi keberhasilan atau kegagalan seseorang dalam menjalankan tugasnya (Pasolong, 2007). Pengukuran kinerja adalah suatu metode atau alat yang digunakan untuk mencatat dan menilai pencapaian pelaksanaan kegiatan berdasarkan tujuan, sasaran dan strategi, sehingga dapat diketahui kemajuan organisasi, serta meningkatkan kualitas pengambilan keputusan dan akuntabilitas (Mahsun, 2006). Penilaian kinerja akan sangat mempengaruhi motivasi kerja (Sanyal dan Biswas, 2014). Penilaian kinerja perlu dilakukan karena karyawan merupakan aset utama suatu organisasi (Kuzu dan Ozilhan, 2014).

Kinerja seseorang juga berhubungan dengan sistem reward. Reward (penghargaan) adalah imbalan jasa yang diberikan perusahaan kepada tenaga kerja karena ia telah memberikan sumbangan tenaga dan pikiran demi kemajuan dan kontinuitas perusahaan dalam rangka mencapai tujuan yang telah ditetapkan baik dalam jangka pendek maupun jangka panjang (Mulyadi, 2001). Sistem reward adalah suatu sistem atau program yang dilaksanakan manajemen dengan memberikan tambahan penerimaan bagi karyawan atau menajer sebagai upaya untuk lebih meningkatkan kinerjanya (Narsa dan Rani, 2003). Simamora (2001) juga mengatakan bahwa sistem penghargaan dibuat untuk meningkatkan produktivitas kerja karyawan. Reward dapat digolongkan ke dalam dua kelompok yaitu reward non-finansial yang berupa rasa puas diri yang diperoleh seseorang yang telah berhasil menyelesaikan pekerjaannya dengan baik dan telah mencapai sasaran tertentu dan reward finansial yang terdiri dari kompensasi yang diberikan kepada karyawan karena prestasi kerjanya baik langsung maupun tidak langsung (Mulyadi, 2007). Pemberian insentif merupakan pemotivasian yang lebih kuat bagi karyawan untuk meningkatkan kualitas kerjanya (Aida \& Listianingsih, 2004).

Universitas Diponegoro (UNDIP) merupakan salah satu organisasi Perguruan Tinggi yang memiliki perhatian besar kepada karyawan. Hal ini ditunjukkan dengan adanya sistem pemberian reward kepada karyawan berdasarkan performansi kinerjanya yang didasarkan atas visi dan misi organisasi. Salah satu bentuk pemberian penghargaan atau reward tersebut diwujudkan dalam bentuk tunjangan peningkatan kinerja (TPK) yang diterimakan setiap bulan. Pemberian TPK yang dilaksanakan berdasarkan hasil penilaian yang dilakukan setiap bulan. Pada tahun 2014 sistem pemberian reward yang ada (TPK) di UNDIP berganti nama dengan Tunjangan Perbaikan Penghasilan, hal ini dikarenakan dalam pemberian TPK dilakukan sebelumnya, pemberian tunjangan dilakukan secara terpisah dengan gaji pokok, mengakibatkan besarnya gaji yang diterima dibawah UMR. Selama ini dasar pemberian TPP yang dilakukan selama ini penekananannya masih pada aspek kedisiplinan, sementara kinerja karyawan tidak cukup hanya dilihat dari aspek kedisiplinan saja.

Berdasarkan permasalahan tersebut, penelitian ini bertujuan memberikan suatu rancangan usulan sistem penilaian terhadap performansi kinerja karyawan di UNDIP. Usulan penilian kinerja ini diharapkan dapat menjadi kerangka acuan dalam pemberian Tunjangan Peningkatan Kinerja (TPK) yang sekarang berganti nama dengan Tunjangan Perbaikan Penghasilan (TPP) kepada karyawan UNDIP. Metode yang digunakan untuk perancangan penilaian kinerja ini adalah AHP (Analytical Hierarchy Process) dan Fuzzy Synthetic Decision Approach. Fungsi dari AHP adalah memberikan bobot penilaian terhadap faktor-faktor yang diturunkan tupoksi yang akan digunakan sebagai faktor penilaian, sedangkan penggunaan Fuzzy Synthetic Decision Approach sebagai metode untuk mengkalkulasi ukuran dengan menggunakan final score dari ukuran yang telah ditetapkan. Jadi dengan pengaplikasian kedua model tersebut diharapkan dapat memberikan penilaian yang obyektif terhadap performansi kinerja karyawan. AHP banyak digunakan dalam proses pemilihan alternatif. Rahimdel dan Ataei (2014) menggunakan AHP untuk pemilihan crusher primer terbaik untuk pertambangan. Agarwal dkk (2013) mengimplementasikan AHP untuk menentukan bobot faktor keselamatan. Bobot faktor keselamatan dan Peringkat faktor keamanan untuk mengembangkan Safety Hazardous Index (SHI) di jalan. Effat dan Hasan (2013) mengintegrasikan faktor lingkungan dan ekonomis melalui model multikriteria spasial menggunakan AHP. Evaluasi multikriteria digunakan untuk membandingkan tiga rute teknik, lingkungan dan hybrid. Rute hybrid akhirnya direkomendasikan. Chen dkk (2011) menggunakan metode fuzzy untuk memilih rencana terbaik dalam perencanaan lingkungan, metode fuzzy multi-kriteria digunakan untuk untuk mengeliminasi subyektifitas responden.

\section{Metodologi \\ Identifikasi Faktor Penilaian Kinerja Karyawan} Identifikasi faktor-faktor penilaian performansi kinerja karyawan dilakukan dengan cara studi literatur terhadap penilaian kinerja yang sudah ada sebelumnya di universitas. Dalam penelitian ini model acuan yang dijadikan dasar dalam membangun model konseptual menggunakan penilaian kinerja karyawan administrasi " Annual Performance Appraisal Temporary Employee" di University of Texas Dallas. Model penilaian kinerja ini terdiri dari 6 kritera dan 19 subkriteria penilaian yang tersaji dalam tabel 1 selanjutnya dilakukan pembobotan menggunakan metode AHP. 


\section{Perancangan Kuesioner Perbandingan Berpasangan}

Kuesioner yang digunakan dalam penelitian ini bertujuan untuk mendapatkan data mengenai tingkat kepentingan dari kriteria yang telah disusun berdasarkan pendapat pihak-pihak yang dianggap mengetahui dan paham mengenai kepegawaian yang ada di lingkungan UNDIP maupun Fakultas Teknik.

\section{Penyebaran Kuesioner}

Penyebaran kuesioner pada penelitian ini akan disebar kepada sampel yang dipilih dengan menggunakan purposive sampling, dimana penyebaran kuesioner dilakukan kepada pihak-pihak yang terkait dengan kepegawaian yang ada di lingkungan UNDIP maupun Fakultas Teknik, dalam penelitian ini pihak yang dilibatkan dalam penyebaran kuesioner perbandingan berpasangan ialah Kepala Subbagian Tenaga Administrasi dan Teknis UNDIP, Pembantu Dekan II Fakultas Teknik, Kepala Tata Usaha Fakultas Teknik dan Kepala SubBagian Keuangan dan Kepegawaian Fakultas Teknik. Kuesioner yang akan disebar ialah kuesioner perbandingan berpasangan antar kriteria yang sudah disusun sebelumnya.

\section{Uji Konsistensi}

Pada tahap ini, hasil kuesioner berpasangan akan diuji kekonsistenannya dengan cara melihat nilai Consistensy Ratio (CR) harus lebih kecil dari 0,1 (Saaty, 2001). Suatu matriks perbandingan berpasangan akan konsisten bila indeks inkonsistensinya berada dibawah nilai 0,1 . Hal tersebut penting karena tanpa adanya ketidak konsistensian maka perubahan yang mempengaruhi tingkat preferensi tidak berlaku.

$$
\mathrm{CI}=\frac{a_{\max }-n}{n-1}
$$

Selanjutnya menghitung CR. CR menyatakan seberapa besar derajat inkonsistensi dari nilai penetapan perbandingan antar kriteria. CR

$$
\text { dirumuskan: } \quad \mathrm{CR}=\frac{C I}{R I}
$$

\section{Pengolahan Data}

Setelah mendapatkan hasil perbandingan kuesioner kriteria dan subkriteria yang konsisten, langkah selanjutnya adalah menghitung bobot untuk masing-masing kriteria dan subkriteria. Perhitungan bobot kriteria dan subkriteria dilakukan dengan menggunakan expert choice 2000.

\section{Penyusunan Form Penilaian Kinerja}

Setelah menghitung bobot masing-masing kriteria selanjutnya dilakukan tahapan penyusunan rancangan penilaian kinerja karyawan menggunakan rating scale dalam bentuk form penilaian.

Rating scale yang akan digunakan menggunakan skala 1-4 sesuai dengan kondisi yang ada saat ini, dan hasil penilaian dengan rating scale dikonversikan sesuai dengan kategori penilaian yang sudah ada saat ini yakni : Sangat Baik nilai 91-100, Baik nilai 81-90, Sedang nilai 80-70 dan Kurang nilai $\leq 69$.

\begin{tabular}{|c|c|}
\hline Kriteria & Subkriteria \\
\hline $\begin{array}{l}\text { Kehadiran / ketepatan } \\
\text { waktu } \\
\text { (A) }\end{array}$ & $\begin{array}{l}\text { Reliabiltias (kehandalan) dalam melaksanakan pekerjaan (A1) } \\
\text { Mampu untuk melakukan penyesuain terhadap jam kerja, hadir tepat waktu baik saat rapat dan kewajiban } \\
\text { kerja yang lain (A2) }\end{array}$ \\
\hline & $\begin{array}{l}\text { Hadir tepat waktu di tempat kerja (dilihat dari absen yang terjadwal) (A3) } \\
\text { Memiliki ketertarikan dalam memunculkan ide (gagasan) dan mengambil tindakan untuk pemecahan suatu } \\
\text { masalah (B1) } \\
\text { Mampu mengambil tindakan yang tepat mengenai kapan bertindak sendiri dan kapan berkonsultasi dengan } \\
\text { orang lain. (B2) }\end{array}$ \\
\hline $\begin{array}{l}\text { Inisiatif } \\
\text { (B) }\end{array}$ & $\begin{array}{l}\text { Memiliki upaya untuk menemukan solusi yang praktis, memiliki banyak akal dan serba guna dalam } \\
\text { menjalankan sebuah tugas yang diberikan. (B3) } \\
\text { Mampu memberi saran dan menerapkan metode untuk peningkatan kerja, serta melaksanakan tugas dengan } \\
\text { sedikit atau tanpa ada peringatan. (B4) }\end{array}$ \\
\hline $\begin{array}{l}\text { Hubungan interpersonal } \\
\text { (C) }\end{array}$ & $\begin{array}{l}\text { Memiliki rasa hormat kepada orang lain, termasuk kepada atasan-bawahan dan rekan-rekan lainnya. (C1) } \\
\text { Menjalin komunikasi dan berhubungan secara efektif dengan rekan sekerja, atasan dan lainnya. (C2) }\end{array}$ \\
\hline $\begin{array}{l}\text { Pengetahuan Pekerjaan } \\
\text { (D) }\end{array}$ & $\begin{array}{l}\text { Memiliki kemampuan dalam bertindak bijak dan berdiplomasi, dan juga bertindak secara profesional. (C3) } \\
\text { Memiliki pemahaman mengenai pengetahuan, keterampilan, proses, perlatan operasi, prosedur dan } \\
\text { kebutuhan sumber daya yang sesuai dengan pekerjaan dan tugas yang diberikan. (D1) }\end{array}$ \\
\hline $\begin{array}{l}\text { Kualitas Pekerjaan } \\
\text { (E) }\end{array}$ & $\begin{array}{l}\text { Pelaksanaan pekerjaan yang akurat dan lengkap. (E1) } \\
\text { Menyampaikan hasil kerja dalam format rapi dan mudah dipahami. (E2) }\end{array}$ \\
\hline $\begin{array}{l}\text { Tanggungjawab dan } \\
\text { Ketergantungan } \\
\qquad(\mathbf{F})\end{array}$ & $\begin{array}{l}\text { Memiliki rasa kebanggaan dan sikap profesionalitas dalam melakukan pekerjaan (E3) } \\
\text { Memilki rasa kepemilikan atas pekerjaan yang ditugaskan (F1) } \\
\text { Memiliki rasa tanggungjawab atas hasil pekerjaan yang dilakukan. (F2) } \\
\text { Mampu memenuhi komitmen, mencukupi batas waktu dan mencapai hasil yang diharapkan dari pekerjaan } \\
\text { yang ditugaskan (F3) } \\
\text { Memiliki sikap kesanggupan melaksanakan tugas baru yang diberikan (F4) } \\
\text { Mampu melakukan penilaian dan memahami penilaian mengenai kepentingan tugas yang diberikan. (F5) }\end{array}$ \\
\hline
\end{tabular}

Tabel 1. Kriteria Dan Sub Kriteria Penilaian Kinerja Karyawan 


\section{Penilaian Kinerja dengan Fuzzy Synthetic} Approach

Setelah menyusun form penilaian kinerja karyawan kontrak administrasi, akan dilakukan uji coba penilaian kepada karyawan kontrak yang ada di Fakultas Teknik dengan fuzzy synthetic approach. Uji coba yang dilakukan untuk memberikan gambaran hasil penerapan penilaian kinerja karyawan dengan form penilaian yang sudah disusun. Dari hasil penilaian tersebut akan diperoleh total bobot penilaian untuk karyawan yang kemudian akan dikonversikan dan akan disesuaikan besarnya TPP sesuai tabel nilai jabatan. Fuzzy relation matrix dirumuskan sebagai berikut

$$
\bar{R}=\left(r_{i j}\right)=\left[\begin{array}{cccc}
r_{11} & r_{12} & \cdots & r_{1 m} \\
r_{21} & r_{22} & \cdots & r_{2 m} \\
\vdots & \vdots & \ddots & \vdots \\
r_{n 1} & r_{n 2} & \cdots & r_{n m}
\end{array}\right]
$$

Dimana:

$r_{i j}=$ rata-rata jumlah komite penilai yang memberikan grade evaluasi pada $\mathrm{j}$ pada faktor $\mathrm{i}$ $(\mathrm{i}=1,2,3, \ldots, \mathrm{n} ; \mathrm{j}=1,2, \ldots \mathrm{m}) \mathrm{jika}:\left(r_{i j}\right)=\frac{x_{i j}}{N}$

$x_{i j}=$ jumlah komite penilai yang memberikan penilaian dengan grade $v_{j}$ untuk faktor $u_{i}$,

$\mathrm{N}=$ Total jumlah komite penilai yang memberikan penilaian $\mathrm{V}$ dengan faktor $\mathrm{U}$.

$\bar{W}=\left(\mathrm{w}_{1}, \mathrm{w}_{2}, \ldots, \mathrm{w}_{\mathrm{n}}\right)$ yang mana $\mathrm{w}_{\mathrm{n}}>$ dan $\sum \mathrm{w}_{\mathrm{n}}=1 . \bar{W}$ menggambarkan tingkat kepentingan relatif dari berbagai macam faktor penilai ditentukan oleh pembuat keputusan yang memiliki otoritas.. $\bar{D}$ menggambarkan penilaian fuzzy secara menyeluruh dari seluruh komite penilai terhadap seseorang yang dinilai. Fuzzy subset di $V$ dirumuskan sebagai

$$
\begin{array}{ll}
\text { berikut : } & \bar{D}=\overline{W^{\circ} R}=\left[\mathrm{d}_{1}, \mathrm{~d}_{2}, \ldots, \mathrm{d}_{\mathrm{m}}\right] \quad \ldots \ldots \ldots . \\
& \mathrm{d}_{1}=\sum_{i=1}^{n}\left(w_{i}{ }^{\circ} r_{i j}\right), \mathrm{j}=1,2, \ldots, \mathrm{m}
\end{array}
$$

\section{Uji Konsistensi}

Perhitungan konsistensi ini menggunakan bantuan software expert choice 2000. Berdasarkan output software, semua hasil dari kuesioner perbandingan berpasangan mempunyai nilai konsistensi dibawah 0,1 seperti yang tersaji pada tabel 3 .

\section{Perhitungan Bobot Kriteria dan Subkriteria}

Dari hasil penyebaran kuesioner yang dilakukan kepada keempat decision maker. Maka didapat bobot kriteria dan subkriteria penilaian kienerja karyawan. Bobot dari kriteria dan sub kriteria dari keempat decision maker. Dimana hasil pembobotan dari keempat decision maker akan dijadikan satu nilai dengan cara menghitung rata-ratanya. Rekapitulasi Bobot Kriteria dan Subkriteria disajikan Tabel 4.
Tabel 3. Nilai Konsistensi

\begin{tabular}{lllll}
\hline Kriteria & D1 & D2 & D3 & D4 \\
CR & 0.06 & 0.06 & 0 & 0.06 \\
$\begin{array}{c}\text { Subkriteria A } \\
\text { CR }\end{array}$ & 0.03 & 0.04 & 0 & 0 \\
$\begin{array}{c}\text { Subkriteria B } \\
\quad \text { CR }\end{array}$ & 0.02 & 0.06 & 0 & 0.06 \\
$\begin{array}{c}\text { Subkriteria C } \\
\text { CR }\end{array}$ & 0 & 0 & 0 & 0 \\
$\begin{array}{c}\text { Subkriteria E } \\
\text { CR }\end{array}$ & 0 & 0.06 & 0 & 0.03 \\
$\begin{array}{c}\text { Subkriteria F } \\
\text { CR }\end{array}$ & 0.08 & 0.08 & 0 & 0.09 \\
\hline
\end{tabular}

\section{Uji Coba Penilaian Kinerja Karyawan dengan pendekatan Fuzzy Synthetic Approach}

Uji coba penilaian kinerja karyawan ke lingkungan Fakultas Teknik UNDIP. Dari hasil pengamatan yang dilakukan jumlah tenaga kerja kontrak administrasi di lingkungan Fakultas Teknik (S1).

\section{Uji Coba Penilaian Kinerja Karyawan dengan pendekatan Fuzzy Synthetic Approach}

Berdasarkan hasil uji coba penilaian kinerja karyawan menggunakan metode fuzzy synthetic decision dilakukan pada karyawan administrasi di lingkungan Fakultas Teknik, Berikut contoh perhitungan penilaiaan kinerja karyawan jurusan Sistem Komputer (SK). Rekapitulasi hasil penilaian aspek kehadiran dan ketepatan waktu karyawan Sk disajikan pada Tabel 5.

Tabel 4. Rekapitulasi Bobot Kriteria dan Subkriteria

\begin{tabular}{ccccc}
\hline K & Bobot & SK & Bobot & $\begin{array}{c}\text { Bobot } \\
\text { Akhir }\end{array}$ \\
\hline A & 0.248 & A1 & 0.375 & 0.093 \\
& & A2 & 0.450 & 0.112 \\
B & \multirow{2}{*}{0.234} & A3 & 0.173 & 0.043 \\
& & B1 & 0.313 & 0.073 \\
& & B2 & 0.183 & 0.043 \\
C & 0.075 & B3 & 0.247 & 0.058 \\
& & B1 & 0.258 & 0.06 \\
& & C2 & 0.333 & 0.025 \\
D & 0.111 & C3 & 0.333 & 0.025 \\
E & 0.139 & D1 & - & 0.025 \\
& & E2 & 0.371 & 0.11 \\
& & E2 & 0.24 & 0.052 \\
F & 0.194 & E3 & 0.387 & 0.033 \\
& & F1 & 0.335 & 0.064 \\
& & F2 & 0.198 & 0.038 \\
& & F3 & 0.123 & 0.024 \\
& & F4 & 0.18 & 0.035 \\
& & F5 & 0.164 & 0.032 \\
\hline
\end{tabular}


Keterangan:

$$
\begin{array}{ll}
\text { K } & \text { : Kriteria } \\
\text { SK } & \text { : Subkriteria }
\end{array}
$$

Tabel 5. Contoh Penilaian Aspek Kehadiran

\begin{tabular}{ccccc}
\hline Pertanyaan & SB & B & S & K \\
\hline A1 & X & & - & - \\
A2 & - & X & - & - \\
A3 & - & X & - & - \\
\hline
\end{tabular}

\section{Keterangan:}

$$
\begin{array}{ll}
\text { SB } & \text { : Sangat Baik } \\
\text { B } & \text { : Baik } \\
\text { S } & \text { : Sedang } \\
\text { K } & \text { : Kurang }
\end{array}
$$

Maka langkah selanjutnya adalah menentukan decision making sets untuk kriteria kehadiran/ ketepatan waktu.

$$
D_{A}=\left[\begin{array}{lll}
0,093 & 0,112 & 0,043
\end{array}\right]^{*}\left[\begin{array}{cccc}
1 & 0 & 0 & 0 \\
0 & 1 & 0 & 0 \\
0 & 1 & 0 & 0
\end{array}\right]
$$

$=\left[\begin{array}{llll}0.093 & 0.155 & 0 & 0\end{array}\right]$

Decision Making Sets diatas akan membentuk skor defusifikasi untuk kriteria kehadiran/ ketepatan waktu, maka langkah selanjutnya akan dikalikan dengan appraisal grading. Maka skor Karyawan SK untuk kriteria kehadiran/ ketepatan waktu diperoleh dengan perhitungan berikut:

Kriteria kehadiran/ ketepatan waktu $=(4 * 0.093)$ $+(3 * 0,155)+(2 * 0)+)+(1 * 0)=0,837$

Total perhitungan hasil penilaian untuk kinerja karyawan SK adalah :

Total $=0.837+0.0702+0.275+0.333+0.469$

$+0.647=\mathbf{3 . 2 6 3}=\mathbf{3 . 2 6}$

Dari hasil uji coba yang dilakukan diperoleh bobot total penilaian 3.26 yang kemudian akan dikalikan dengan 25. Berikut contoh perhitungan nilai akhir karyawan Sistem Komputer (SK) :

Nilai Akhir $=3.26 \times 25=\mathbf{8 1 . 5}$

\section{Perhitungan Tunjangan Perbaikan Penghasilan (TPP)}

Dalam melakukan perhitungan TPP terlebih dahulu nilai akhir akan dikonversikan berdasarkan tabel konversi, yang selanjutnya akan dilakukan perhitungan TPP dengan menggunakan rumus 6:

$$
\text { TPP = FP x NJ x IDrp }
$$

Keterangan :

FP $\quad=$ Faktor Penyesuai

NJ = Nilai Jabatan (Standar Univ)

IDrp = Indeks Besaran Rupiah

Berikut contoh perhitungan nilai konversi dari pegawai SK adalah sebagai berikut :

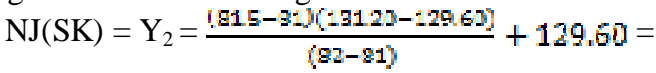

$$
\begin{aligned}
& 130.4
\end{aligned}
$$

Maka TPP yang akan diterima oleh karyawan SK adalah :

$\mathrm{TPP}=1 \times 130.4$ × Rp. $4,500=$ Rp. 586,800

Rekapitulasi TPP yang diberikan disajikan pada Tabel 6.

Tabel 6. Rekapitulasi TPP

\begin{tabular}{ccc}
\hline NO & KARYAWAN & TPP \\
\hline 1 & SK & Rp. 586,800 \\
2 & TI(1) & Rp. 396,000 \\
3 & TI(2) & Rp. 508,500 \\
4 & TP(1) & Rp. 560,430 \\
5 & TP(2) & Rp. 548,280 \\
6 & TP(3) & Rp. 676,800 \\
7 & DK(1) & Rp. 698,400 \\
8 & DK(2) & Rp. 979,605 \\
9 & DK(3) & Rp. 480,600 \\
10 & DK(4) & Rp. 825,210 \\
11 & DK(5) & Rp. 414,630 \\
13 & DK(7) & Rp. 619,200 \\
14 & DK(8) & Rp. 731,520 \\
15 & PWK(1) & Rp. 514,800 \\
16 & PWK(2) & Rp. 439,200 \\
17 & PWK(3) & Rp. 845,460 \\
18 & PWK(4) & Rp. 462,600 \\
19 & PWK(5) & Rp. 504,000 \\
20 & PWK(6) & Rp. 504,000 \\
21 & PWK(7) & Rp. 759,375 \\
\hline & &
\end{tabular}

\section{Analisis Perancangan Penilaian Kinerja Karyawan}

Perancangan Penilaian Kinerja Karyawan yang dilakukan dalam penelitian ini menggunakan model penilaian kinerja karyawan adminsitrasi yang berjudul "Annual Performance Appraisal-Temporary Employee (Classified or Administrative and Professional), The University of Texas at Dallas, January 2014”. Model penilaian kinerja karyawan administrasi ini digunakan di The University of Texas at Dallas sejak tahun 2014. Model penilaian kinerja ini memiliki 6 kriteria dan 19 subkriteria penilaian kinerja karyawan. Berdasarkan dari hasil penyesuaian dan studi pustaka yang dilakukan menggunakan buku dengan judul "Improving Employee Performance Through appraisal and Coaching, second edition" diperoleh 6 kriteria dan 19 subkriteria seperti yang tersaji pada Tabel 1. Dari hasil pembobotan yang disajikan pada Tabel 4 diketahui bahwa kriteria yang memiliki bobot terbesar adalah kehadiran/ketepatan waktu dimana hal ini menunjukkan bahwa kritia ini dianggap lebih penting dalam melakukan penilaian yang didukung juga dengan adanya sistem finger print yang sudah ada di UNDIP. 


\section{Analisis Penetuan Bobot Penilaian Kinerja Karyawan}

Kuesioner perbandingan berpasangan tersebut dibagikan kepada keempat decision maker yang dipilih dengan menggunakan purposive sampling, teknik sampling ini dipilih dikarenakan responden yang digunakan adalah orang-orang yang memiliki kriteria tertentu, yakni memiliki pengetahuan dan kemampuan dalam mengambil keputusan yang terkait dengan karyawan di Fakultas Teknik UNDIP. Pada Tabel 3 menunjukkan bahwa hasil kuesioner yang diberikan sudah konsisten.

\section{Analisis Usulan Kerangka Pemberian Tunjangan Perbaikan Penghasilan (TPP)}

Dari hasil perhitungan rata-rata pemberian TPP yang akan diberikan kepada 21 orang karyawan berdasarkan tingkat pendidikan karyawan adalah Rp. 504,540 untuk karyawan kontrak dengan tingkat pendidikan SMA; Rp. 539,390.5 untuk karyawan kontrak dengan tingkat pendidikan DIII; dan Rp.821,164,4 untuk karyawan kontrak dengan tingkat pendidikan S1.

\section{Kesimpulan}

Penilaian kinerja karyawan yang dirancang terdiri dari 6 kriteria penilaian dan 19 subkriteria penilaian. Dimana urutan bobot yang didapatkan untuk kriteria kehadiran/ketepatan waktu sebesar 0.248 ; kriteria inisatif 0.234 ; kriteria tanggung jawab dan 0.194; kriteria kualitas pekerjaan 0.139; kriteria pengetahuan pekerjaan 0.111 dan kriteria hubungan interpersonal 0.075 .

Dari hasil uji coba penilaian kinerja yang dilakukan dengan Fuzzy Synthethic Approach hasil perhitungan TPP, seperti yang disajikan pada, didapatkan bahwa besarnya TPP yang terbesar ialah Rp. 979,605,sedangkan TPP yang terkecil Rp.396,000. Besar-kecilnya pemberian TPP dipengaruhi oleh nilai jabatan yang dihasilkan.

\section{Daftar Pustaka}

Agarwal, P.K, Patil, P.K and Mehar, R, 2014. A Methodology for Ranking Road Safety Hazardous Locations Using Analytical Hierarchy Process, Procedia - Social and Behavioral Sciences, Vol104, Pages 1030-1037

Annual Performance Appraisal Temporary Employee (Classified or Administrative and Professional.utdallas.edu. Diakses 15 Mei, 2014 dari http://www.utdallas.edu/hrm/forms/

Aida \& Listianingsih. 2004. Pengaruh Sistem Pengukuran Kinerja Sistem Reward dan Profit Center Terhadap Hubungan Antara Total Quality Management dengan Kinerja Manajerial. SNA VIII. Solo
Bedarkar, M. and Pandita, D. 2014. A Study on the Drivers of Employee Engagement Impacting Employee Performance, Procedia - Social and Behavioral Sciences, Volume 133, Pages 106115

Chen, Vivien Y.C, Lien, Hui-Pang., Liu, Chui Hua, Liou, James J.H., Tzeng, Gwo-Hashiung, and Yang Lung-Shi. 2011. Fuzzy MCDM approach for selecting the best environment-watershed plan, Applied Soft Computing, Volume 11, Issue 1, Pages 265-275

Effat, H.A and Hassan, O.A. 2013. Designing and evaluation of three alternatives highway routes using the Analytical Hierarchy Process and the least-cost path analysis, application in Sinai Peninsula, Egypt. The Egyptian Journal of Remote Sensing and Space Science. Volume 16, Issue 2, Pages 141-151

I Made Narsa \& Rani Dwi Yuniawati. 2003. Pengaruh Interaksi Total Quality Manajemen dengan Sistem Pangukuran Kinerja dan Sistem Penghargaan terhadap Kinerja Manajerial. Jurnal Ekonomi Akuntansi, Fakultas EkonomiUniversitas Kristen Petra.

Kuzu, O.H and Ozilhan, D. 2014. The Effect of Employee Relationships and Knowledge Sharing on Employees' Performance: An Empirical Research on Service Industry, Procedia - Social and Behavioral Sciences, Volume 109, Pages 1370-1374

Mahsun, M. 2006. Pengukuran Kinerja Sektor Publik. Yogyakarta: Penerbit BPFE

Mulyadi dan Johny. 2001. Sistem Perencanaan dan Pengendalian Manajemen. Edisi Kedua. Jakarta: Salemba Empat.

Mulyadi, 2007. Sistem Perencanaan dan Pengendalian Manajemen. Jakarta: Salemba Empat.

Pasolong, Ha. 2007. Teori Administrasi Publik. Bandung: Alfabete

Rahimdel, M.J and Ataei, M. 2014. Application of analytical hierarchy process to selection of primary crusher, International Journal of Mining Science and Technology, Volume 24, Issue 4, Pages 519-523

Saaty, T.L. 2001. The Analytical Hierarchy Process,Pittssburgh:RWS Publication.

Sanyal, M.K and Biswas, S.B. 2014. Employee Motivation from Performance Appraisal Implications: Test of a Theory in the Software Industry in West Bengal (India), Procedia Economics and Finance, Volume 11, Pages 182196

Simamora, H. 2001. Manajemen Sumber Daya Manusia. Jakarta: Bina Rupa Aksara. 